\title{
Pengaruh Komposisi Media Tanam terhadap Pertumbuhan Bibit Asam Jawa dan Asam Manis (Tamarindus indica L.)
}

\section{Effect of Plant Media Composition On Growth Of Javanese Tamarind and Sweet Tamarind (Tamarindus indica L.)}

\author{
Aisyah Puspasari, Rohlan Rogomulyo*), Didik Indradewa \\ Departemen Budidaya Pertanian, Fakultas Pertanian, Universitas Gadjah Mada \\ Jalan Flora No. 1, Bulaksumur, Sleman, Yogyakarta 55281, Indonesia. \\ ${ }^{*}$ Penulis untuk korespondensi Email: rohlan_rm@yahoo.com
}

\begin{abstract}
Tamarind plants are important plants that have potential, but have not been considered. Tamarind plants have the benefits of traditional spices and herbs. There has been no research on what is good plant media composition of javanese tamarind and sweet tamarind. Based on that, conducted research about "The Effect of Plant Media Composition on Growth of Javanese Tamarind and Sweet Tamarind (Tamarindus indica L.)". The purpose of this research is to study the effect of plant media composition on the growth of javanese tamarind and sweet tamarind. This research has been conducted from August 2017 to December 2017 at Agro Technology Innovation Centre Universitas Gadjah Mada, Berbah, Yogyakarta. This research used RCBD (Randomized Complete Block Design) of factor $4 \times 2$ and three blocks as replication. The first factor is plant media composition are soil : manure : charcoal husk 4 : 0 : 0 , soil : manure : charcoal husk $2: 1$ : 1, soil : manure : charcoal husk $1: 2: 1$, soil : manure : charcoal husk $1: 1: 2$. The second factor is types of plants are javanese tamarind and sweet tamarind. The observed data were analyzed by variance at 95\% confidence level. If there is a real difference between treatments, tested further with DMRT (Duncan Multiple Range Test). The result obtained there is no effect of combination of plant media treatment to the growth of javanese tamarind and sweet tamarind.
\end{abstract}

Keywords: javanese tamarind, sweet tamarind, plant media

\section{INTISARI}

Tanaman asam merupakan tanaman penting yang mempunyai potensi, tetapi kurang diperhatikan. Tanaman asam mempunyai manfaat sebagai rempah dan jamu tradisional. Tidak ada penelitian mengenai bagaimana komposisi media tanam yang baik untuk asam jawa dan asam manis. Atas dasar tersebut dilakukan penelitian "Pengaruh Komposisi Media Tanam terhadap Pertumbuhan Bibit Asam Jawa dan Asam Manis (Tamarindus indica L.)". Tujuan penelitian ini adalah mempelajari pengaruh komposisi media tanam terhadap pertumbuhan bibit asam jawa dan asam manis. Penelitian ini telah dilaksanakan pada bulan Agustus 2017 sampai Desember 2017 di Pusat Inovasi Agroteknologi Universitas Gadjah Mada, Berbah, Yogyakarta. Penelitian ini menggunakan RAKL (Rancangan Acak Kelompok Lengkap) faktorial $4 \times 2$ dan tiga blok sebagai ulangan. Faktor pertama komposisi media tanam antara tanah : pupuk kandang 
: arang sekam $4: 0: 0$, tanah : pupuk kandang : arang sekam $2: 1: 1$, tanah : pupuk kandang : arang sekam $1: 2: 1$, tanah : pupuk kandang : arang sekam 1 : 1 : 2. Faktor kedua jenis asam antara: asam jawa dan asam manis. Data hasil pengamatan dianalisis varians pada tingkat keprcayaan 95\%. Apabila terdapat beda nyata antar perlakuan, diuji lanjut dengan DMRT (Duncan Multiple Range Test). Hasil yang diperoleh tidak terdapat pengaruh kombinasi perlakuan media tanam terhadap pertumbuhan bibit asam jawa dan asam manis.

Kata kunci: asam jawa, asam manis, media tanam

\section{PENDAHULUAN}

Asam merupakan tanaman penting, pohon untuk konservasi tanah dan air, dan buah mempunyai banyak manfaat. Asam manis sebagai buah segar asam jawa untuk bahan jamu tradisional. Asam masih belum banyak dibudidayakan karena mudah tumbuh secara alami. Buah asam yang dihasilkan terkadang tidak dipanen apalagi dimanfaatkan. Pada saat ini, tanaman asam ditanam masih terbatas sebagai tanaman pekarangan dan tanaman pelindung. Kebanyakan tanaman asam tumbuh secara alami di pekarangan. Belum banyak yang berminat untuk berkebun tanaman asam.

Pembibitan tanaman asam sangat penting untuk konservasi dan sumber genetik berkelanjutan (Azad et al., 2014). Kayu asam yang keras dapat digunakan sebagai alat pertanian, di Amerika dikenal sebagai madeira mahogani (Hamid, 1995). Buah asam dikenal di seluruh dunia karena banyak dikonsumsi dengan manfaat luas (Rismunandar, 1986). Buah asam terdiri dari 55\% pulp, 33,9\% biji, dan 11,1\% kulit dan serat buahnya (Hamid, 1995). Buah asam matang mempunyai $40 \%-50 \%$ bagian yang dapat dimakan (Ashari, 1995; Wongsowijoyo, 2013). Buah asam digunakan sebagai obat demam di Senegal. Hampir semua bagian asam dapat digunakan sebagai obat disentri (Havinga et al., 2010).

Berdasarkan World Health Organization, buah tamarind adalah sumber ideal untuk semua asam amino penting kecuali tryptophan. Biji asam pun mempunyai sifat serupa. Asam menjadi penting untuk ketersedian sumber protein, terutama di negara mal nutrisi (Kuru, 2014). Tamarindus indica Fruit Shell Carbon (TIFSC) atau kulit buah asam secara alami mengandung kalsium karbonat yang tinggi. Oleh karena itu, TIFSC dapat menghilangkan kontaminasi fluoride secara efektif di dalam tanah pada $\mathrm{pH}$ netral 7,05 (Sivasankar et al., 2012).

Bibit asam dapat dihasilkan dengan biaya yang lebih murah dan mudah didapatkan perlu menggunakan komposisi yang seimbang antara lain tanah, pupuk kandang, dan arang sekam. Tanah regosol yang cenderung berpasir dikombinasikan dengan pupuk kandang yang lebih padat membuat agregat tanah menjadi lebih besar 
sehingga daya simpan air, pertukaran ion, dan kehidupan mikroorganisme lebih baik. Arang sekam mempunyai daya simpan dan daya lepas air lebih baik.

Penelitian dan budidaya tanaman asam masih jarang dilakukan. Kurangnya informasi mengenai tanaman asam membuat ketidaktahuan mengenai manfaat tanaman asam dan cara budidayanya. Langkanya tanaman asam dengan manfaat dan kebutuhan yang cukup tinggi, menandakan perlunya peningkatan mutu dari budidaya tanaman asam. Tahap awal budidaya, yaitu pembibitan, perlu lebih dulu dikembangkan mengingat masih sedikitnya populasi tanaman asam. Ke depan, saat tanaman asam banyak dan mulai menghasilkan, kualitas buah perlu dikembangkan.

Bagaimanakah komposisi media tanam yang baik untuk masing-masing jenis asam belum ada penelitian yang dilakukan. Atas dasar tersebut perlu dibuat penelitian. Mempelajari sifat perakaran bibit asam jawa dan asam manis. Mempelajari pengaruh komposisi media tanam terhadap pertumbuhan bibit asam jawa dan asam manis. Hasil penelitian diharapkan sekaligus dapat menghasilkan bibit asam yang unggul untuk ke depan.

Tujuan penelitian adalah mempelajari pengaruh komposisi media tanam terhadap pertumbuhan bibit asam jawa dan asam manis dan mendapatkan komposisi media tanam terbaik untuk bibit asam jawa dan asam manis. Landasan teori bahwa jenis asam dapat dibedakan berdasarkan rasa buah menjadi tipe manis dan asam (ElSiddig et al., 2006). Kebanyakan asam berasa asam seperti asam jawa, tetapi ada pula asam yang berasa manis atau dikenal dengan nama sweet tamarind dari Thailand (Arifin, 2010). Hal ini menunjukkan adanya kemungkinan perbedaan antara asam jawa dan asam manis pada budidaya dan morfologi secara vegetatif.

\section{BAHAN DAN METODE}

Penelitian telah dilaksanakan pada bulan Agustus-Desember 2017 di UGM Pusat Inovasi Agroteknologi Universitas Gadjah Mada, Berbah, Yogyakarta. Alat yang digunakan adalah cangkul, cetok, gembor, alat tulis, paranet, Leaf Area Meter (LAM), timbangan elektrik, dan oven. Bahan yang digunakan adalah biji asam jawa, biji asam manis, tanah, pupuk kandang, arang sekam, polybag, label, fungisida, dan insektisida. Biji asam jawa dan asam manis didapatkan dari daerah Yogyakarta.

Penelitian ini menggunakan rancangan perlakuan faktorial $4 \times 2$ dengan tata letak acak kelompok dan tiga blok sebagai ulangan. Faktor I komposisi media tanam $(400,211,121,112)$ dan faktor II jenis tanaman asam jawa $(\mathrm{J})$ dan jenis tanaman 
asam manis (M). Terdapat 24 unit percobaan dan masing-masing unit percobaan terdiri atas 20 tanaman dan didapatkan 480 bibit tanaman asam.

Faktor I . Komposisi Media Tanam:

$400=$ tanah : pupuk kandang $:$ arang sekam $=4: 0: 0$

$211=$ tanah : pupuk kandang $:$ arang sekam $=2: 1: 1$

$121=$ tanah $:$ pupuk kandang : arang sekam $=1: 2: 1$

$112=$ tanah $:$ pupuk kandang : arang sekam $=1: 1: 2$

Faktor II. Jenis Tanaman Asam:

$\mathrm{J}$ = asam jawa $\mathrm{M}=$ asam manis

Pengamatan penelitian berupa kadar lengas, berat volume, tinggi tanaman, diameter batang, jumlah daun, luas daun, bobot segar batang, daun, dan akar, bobot kering batang, daun, dan akar, luas akar, panjang akar, kadar air nisbi, stomata, klorofil, laju asimilasi bersih (lab), laju pertumbuhan nisibi. Data hasil pengamatan dianalisis dengan analisis varian tingkat kepercayaan $95 \%$. Apabila terdapat beda nyata antarperlakuan, diuji lanjut dengan Duncan Multiple Range Test (DMRT) tingkat kepercayaan $95 \%$.

\section{HASIL DAN PEMBAHASAN}

Hasil penelitian menunjukkan bahwa tidak ada interaksi antara perlakuan jenis asam (asam jawa dan asam manis) dengan komposisi media tanam (tanah : pupuk : arang sekam) pada semua variabel atau parameter pengamatan. 
Tabel 1. Rangkuman pengaruh jenis asam terhadap variabel pengamatan

\begin{tabular}{|c|c|c|}
\hline \multirow{2}{*}{ Variabel } & \multicolumn{2}{|c|}{ Jenis Asam } \\
\hline & Asam Jawa & Asam Manis \\
\hline Berat volume $16 \mathrm{mst}(\mathrm{g} / \mathrm{cc})$ & $0,79 p$ & $0,79 p$ \\
\hline Kadar lengas 16 mst (\% ) & $49 \mathrm{p}$ & $45 p$ \\
\hline Panjang akar 8 mst (cm ) & $5,44 \mathrm{p}$ & $6,13 p$ \\
\hline Panjang akar 16 mst $(\mathrm{cm})$ & $13,99 p$ & $17,50 p$ \\
\hline Luas akar $8 \mathrm{mst}\left(\mathrm{cm}^{2}\right)$ & $15,80 p$ & $13,47 p$ \\
\hline Luas akar 16 mst $\left(\mathrm{cm}^{2}\right)$ & $36,13 p$ & $34,39 p$ \\
\hline Kadar air nisbi 8 mst (gram) & $0,90 p$ & $0,91 p$ \\
\hline Kadar air nisbi 16 mst (gram) & $0,70 p$ & $0,74 p$ \\
\hline Jumlah daun $4 \mathrm{mst}$ & $4,21 p$ & $3,88 p$ \\
\hline Jumlah daun $8 \mathrm{mst}$ & $9,46 p$ & $8,04 \mathrm{q}$ \\
\hline Jumlah daun $12 \mathrm{mst}$ & $9,88 p$ & $9,46 p$ \\
\hline Jumlah daun 16 mst & $17,79 p$ & $15,83 p$ \\
\hline Luas daun $8 \mathrm{mst}\left(\mathrm{cm}^{2}\right)$ & $92,42 p$ & $80,21 p$ \\
\hline Luas daun 16 mst $\left(\mathrm{cm}^{2}\right)$ & $114,5 p$ & $101,3 p$ \\
\hline Klorofil total $8 \mathrm{mst}(\mathrm{mg} / \mathrm{g})$ & $0,19 p$ & $0,18 p$ \\
\hline Klorofil total $16 \mathrm{mst}(\mathrm{mg} / \mathrm{g})$ & $0,17 q$ & $0,19 p$ \\
\hline Densitas stomata $8 \mathrm{mst}\left(/ \mathrm{mm}^{2}\right)$ & $77,08 \mathrm{q}$ & $98,96 p$ \\
\hline Densitas stomata $16 \mathrm{mst}\left(/ \mathrm{mm}^{2}\right)$ & $80,52 p$ & $63,75 \mathrm{q}$ \\
\hline LAB (gram/dm²/minggu) & $0,185 p$ & $0,150 p$ \\
\hline LPN (gram/minggu) & $0,106 p$ & $0,082 p$ \\
\hline Bobot segar $8 \mathrm{mst}$ (gram) & $2,22 p$ & $1,87 \mathrm{q}$ \\
\hline Bobot segar 16 mst (gram) & $4,71 p$ & $3,67 q$ \\
\hline Bobot kering $8 \mathrm{mst}$ (gram) & $0,72 p$ & $0,62 \mathrm{q}$ \\
\hline Bobot kering 16 mst (gram) & $1,57 \mathrm{p}$ & $1,27 \mathrm{p}$ \\
\hline Tinggi tanaman 4 mst $(\mathrm{cm})$ & $15,08 p$ & $13,58 \mathrm{q}$ \\
\hline Tinggi tanaman $8 \mathrm{mst}(\mathrm{cm})$ & $24,71 p$ & $19,88 \mathrm{q}$ \\
\hline Tinggi tanaman $12 \mathrm{mst}(\mathrm{cm})$ & $31,21 \mathrm{p}$ & $25,19 \mathrm{q}$ \\
\hline Tinggi tanaman 16 mst $(\mathrm{cm})$ & $34,04 p$ & $27,42 \mathrm{q}$ \\
\hline Diameter batang $4 \mathrm{mst}(\mathrm{cm})$ & $0,24 p$ & $0,24 p$ \\
\hline Diameter batang $8 \mathrm{mst}(\mathrm{cm})$ & $0,30 p$ & $0,30 p$ \\
\hline Diameter batang $12 \mathrm{mst}(\mathrm{cm})$ & $0,33 p$ & $0,35 p$ \\
\hline Diameter batang $16 \mathrm{mst}(\mathrm{cm})$ & $0,35 p$ & $0,36 p$ \\
\hline
\end{tabular}

Keterangan: Angka pada baris dan kolom rerata diikuti huruf yang sama menunjukkan tidak beda nyata pada DMRT dengan taraf kepercayaan $95 \%$.

Dari Tabel 1, dapat diperoleh hasil bahwa terdapat pengaruh asam jawa dan asam manis pada parameter pengamatan klorofil total, densitas stomata, bobot segar, bobot kering, tinggi tanaman. Di samping itu, Tabel 1 menunjukkan tidak ada pengaruh jenis asam terhadap variabel pengamatan lainnya.

Bobot segar bibit asam manis lebih ringan dibandingkan bibit asam jawa. Bobot kering bibit asam manis tidak beda nyata dibandingkan bibit asam jawa, namun cenderung lebih ringan. Dengan bobot segar dan bobot kering tersebut, bibit asam manis nyata lebih pendek dibandingkan bibit asam jawa. Disertai dengan jumlah daun bibit asam manis yang cenderung lebih sedikit meskipun tidak beda nyata dan diameter batang yang tidak beda nyata dibandingkan asam jawa. Rendahnya 
pertumbuhan bibit asam manis ini terjadi karena bibit asam manis meskipun mempunyai kadar klorofil lebih tinggi, tetapi mempunyai densitas stomata lebih rendah dibandingkan bibit asam jawa. Oleh karena itu, bibit asam manis diduga mempunyai kemampuan fotosintesis lebih rendah disbanding bibit asam jawa. Dilihat dari perakarannya, pengaruh jenis asam terhadap berat volume, kadar lengas, panjang akar, luas akar, dan kadar air nisbi bibit asam manis tidak beda nyata dibandingkan bibit asam jawa. Walaupun, bibit asam manis cenderung mempunyai panjang akar lebih panjang dan luas akar lebih sedikit. Disertai dengan LAB (Laju Asimilasi Bersih) dan LPN (Laju Pertumbuhan Nisbi) bibit asam manis yang tidak beda nyata meskipun cenderung lebih rendah dibandingkan dengan bibit asam jawa.

Pertumbuhan akar mempengaruhi pertumbuhan daun. Tidak ada pengaruh luas daun terhadap jenis asam di mana asam manis sama baik dibandingkan dengan asam jawa pada 8 dan 16 mst. Namun, secara genetis, klorofil total dan densitas stomata mempunyai perbedaan terhadap jenis asam. Tidak ada pengaruh klorofil total terhadap jenis asam di mana asam manis sama baik dibandingkan dengan asam jawa pada 8 mst dan telah ada pengaruh klorofil total terhadap jenis asam di mana asam manis lebih banyak dibandingkan dengan asam jawa pada $16 \mathrm{mst}$. Telah ada pengaruh densitas stomata terhadap jenis asam di mana asam manis lebih banyak dibandingkan dengan asam jawa pada 8 mst namun kemudian asam manis tidak lebih banyak bila dibandingkan dengan asam jawa padaa $16 \mathrm{mst}$.

Kemampuan daun menangkap cahaya matahari, melangsungkan fotosintesis, dan menghasilkan fotosintat dilihat dari luas daun, klorofil total, dan densitas stomata mempengaruhi laju asimilasi bersih dan laju pertumbuhan tanaman. Atau dengan kata lain laju fotosintesis menghasilkan asimilat atau laju pembentukan asimilat dalam bentuk bobot kering untuk pertumbuhan tanaman. Tidak ada pengaruh laju asimilasi bersih dan laju pertumbuhantanaman, terhadap jenis asam di mana asam manis sama baik dibandingkan dengan asam jawa pada 8 dan dan 16 mst.

Laju asimilasi bersih dan laju pertumbuhan tanaman mempengaruhi pembentukan tinggi tanaman, jumlah daun, dan diameter batang. Tinggi tanaman membantu pertumbuhan daun untuk menangkap cahaya matahari dan melangsungkan proses fotosintesis. Jumlah daun menentukan kapasitas tanaman dapat melakukan proses fotosintesis. Diameter batang sebagai tempat pertumbuhan xilem dan floem untuk distribusi air, unsur hara, dan asimilat. Telah ada pengaruh tinggi tanaman terhadap jenis asam di mana asam manis tidak lebih tinggi dibandingkan dengan asam jawa pada 4 mst sampai 16 mst. Tidak ada pengaruh jumlah daun dan diameter 
batang terhadap jenis asam di mana asam manis sama dibandingkan dengan asam jawa pada 4 mst sampai 16 mst.

Pertumbuhan tanaman menghasilkan asimilat dan ada pula kandungan air di dalam tanaman yang mempengaruhi bobot segar. Telah ada pengaruh bobot segar terhadap jenis asam di mana asam manis tidak lebih berat dibandingkan dengan asam jawa pada 8 mst dan 16 mst. Pertumbuhan tanaman menghasilkan asimilat membentuk bobot kering. Telah ada pengaruh bobot kering terhadap jenis asam di mana asam manis tidak lebih berat dibandingkan asam jawa pada 8 mst. Tidak ada pengaruh bobot kering terhadap jenis asam di mana asam manis sama baik dibandingkan dengan asam jawa pada 16 mst.

Hasil penelitian menunjukkan bahwa tidak ada interaksi antara perlakuan jenis asam (asam jawa dan asam manis) dengan komposisi media tanam (tanah : pupuk : arang sekam) pada semua variabel pengamatan. 
Tabel 2. Rangkuman pengaruh komposisi media tanam terhadap variabel pengamatan

\begin{tabular}{|c|c|c|c|c|}
\hline \multirow{2}{*}{ variabel } & \multicolumn{4}{|c|}{ komposisi media tanam tanah : pupuk : arang sekam } \\
\hline & $4: 0: 0$ & $2: 1: 1$ & $1: 2: 1$ & $1: 1: 2$ \\
\hline Berat volume $0 \mathrm{mst}(\mathrm{g} / \mathrm{cc})$ & $1,01 \mathrm{a}$ & $0,79 \mathrm{~b}$ & $0,45 \mathrm{c}$ & $0,38 \mathrm{~d}$ \\
\hline Berat volume $16 \mathrm{mst}(\mathrm{g} / \mathrm{cc})$ & $1,13 \mathrm{a}$ & $0,82 \mathrm{~b}$ & $0,68 \mathrm{c}$ & $0,52 \mathrm{~d}$ \\
\hline Kadar lengas 0 mst (\% ) & $28 \mathrm{bc}$ & $34 a b$ & $25 \mathrm{c}$ & $37 \mathrm{a}$ \\
\hline Kadar lengas 16 mst (\% ) & $27 \mathrm{a}$ & $48 \mathrm{a}$ & 55 a & $59 a$ \\
\hline Panjang akar $8 \mathrm{mst}(\mathrm{cm})$ & $5,62 \mathrm{a}$ & $6,12 \mathrm{a}$ & 4,95 a & $6,43 a$ \\
\hline Panjang akar $16 \mathrm{mst}(\mathrm{cm})$ & $15,30 \mathrm{a}$ & $17,23 \mathrm{a}$ & 16,27 a & $14,18 \mathrm{a}$ \\
\hline Luas akar $8 \mathrm{mst}\left(\mathrm{cm}^{2}\right)$ & $12,52 \mathrm{~b}$ & $12,68 \mathrm{~b}$ & $12,50 \mathrm{~b}$ & $20,84 \mathrm{a}$ \\
\hline Luas akar 16 mst $\left(\mathrm{cm}^{2}\right)$ & 29,26 a & 37,87 a & $36,10 \mathrm{a}$ & $37,83 \mathrm{a}$ \\
\hline Kadar air nisbi 8 mst(gram) & $0,89 a$ & $0,93 \mathrm{a}$ & 0,89 a & $0,92 \mathrm{a}$ \\
\hline Kadar air nisbi 16 mst(gram) & $0,73 a$ & $0,71 \mathrm{a}$ & $0,73 \mathrm{a}$ & $0,70 \mathrm{a}$ \\
\hline Jumlah daun 4 mst & 3,75 a & $4,00 \mathrm{a}$ & $4,17 \mathrm{a}$ & $4,25 \mathrm{a}$ \\
\hline Jumlah daun $8 \mathrm{mst}$ & $9,00 \mathrm{a}$ & $9,33 \mathrm{a}$ & $8,00 \mathrm{a}$ & $8,67 \mathrm{a}$ \\
\hline Jumlah daun 12 mst & 9,75 a & $8,92 \mathrm{a}$ & 9,75 a & $10,25 a$ \\
\hline Jumlah daun 16 mst & $16,17 \mathrm{a}$ & $17,00 \mathrm{a}$ & 18,17 a & $15,92 \mathrm{a}$ \\
\hline Luas daun $8 \mathrm{mst}\left(\mathrm{cm}^{2}\right)$ & 85,68 a & 75,20 a & 90,08 a & $94,30 \mathrm{a}$ \\
\hline Luas daun 16 mst $\left(\mathrm{cm}^{2}\right)$ & $108,3 \mathrm{a}$ & 107,95 a & $105,67 \mathrm{a}$ & $109,81 \mathrm{a}$ \\
\hline Klorofil total $8 \mathrm{mst}(\mathrm{mg} / \mathrm{g})$ & $0,20 \mathrm{a}$ & $0,18 \mathrm{a}$ & $0,18 a$ & $0,18 \mathrm{a}$ \\
\hline Klorofil total $16 \mathrm{mst}(\mathrm{mg} / \mathrm{g})$ & $0,18 a$ & $0,17 \mathrm{a}$ & $0,18 a$ & $0,17 \mathrm{a}$ \\
\hline Densitas stomata $8 \mathrm{mst}\left(/ \mathrm{mm}^{2}\right)$ & 83,75 a & 75,63 a & 94,17 a & $98,54 \mathrm{a}$ \\
\hline Densitas stomata16mst $\left(/ \mathrm{mm}^{2}\right)$ & 63,96 a & $85,42 \mathrm{a}$ & 80,63 a & $58,54 \mathrm{a}$ \\
\hline LAB (gram/dm²/minggu) & $0,173 a$ & $0,195 a$ & $0,138 a$ & $0,163 a$ \\
\hline LPN (gram/minggu) & $0,089 a$ & $0,102 a$ & $0,081 \mathrm{a}$ & $0,103 a$ \\
\hline Bobot segar $8 \mathrm{mst}$ (gram) & $2,11 \mathrm{a}$ & $1,75 \mathrm{a}$ & $2,14 a$ & $2,19 a$ \\
\hline Bobot segar 16 mst (gram) & 3,99 a & $4,25 a$ & $4,02 \mathrm{a}$ & $4,50 \mathrm{a}$ \\
\hline Bobot kering $8 \mathrm{mst}$ (gram) & $0,68 \mathrm{a}$ & $0,57 \mathrm{a}$ & $0,71 \mathrm{a}$ & $0,73 a$ \\
\hline Bobot kering 16 mst (gram) & $1,39 a$ & $1,39 a$ & 1,36 a & $1,55 \mathrm{a}$ \\
\hline Tinggi tanaman $4 \mathrm{mst}(\mathrm{cm})$ & 13,58 a & $14,75 a$ & $13,54 \mathrm{a}$ & $15,46 a$ \\
\hline Tinggi tanaman $8 \mathrm{mst}(\mathrm{cm})$ & $21,08 b$ & $23,50 a b$ & $20,38 \mathrm{c}$ & $24,21 \mathrm{a}$ \\
\hline Tinggi tanaman $12 \mathrm{mst}(\mathrm{cm})$ & $24,79 \mathrm{~b}$ & $29,21 a b$ & $26,83 b$ & $31,96 a$ \\
\hline Tinggi tanaman $16 \mathrm{mst}(\mathrm{cm})$ & 26,63 a & 31,58 a & $29,71 \mathrm{a}$ & $35,00 \mathrm{a}$ \\
\hline Diameter batang $4 \mathrm{mst}(\mathrm{cm})$ & $0,25 a$ & $0,24 a$ & $0,23 a$ & $0,22 \mathrm{a}$ \\
\hline Diameter batang $8 \mathrm{mst}(\mathrm{cm})$ & $0,30 \mathrm{a}$ & $0,31 \mathrm{a}$ & $0,29 a$ & $0,30 a$ \\
\hline Diameter batang $12 \mathrm{mst}(\mathrm{cm})$ & $0,35 a$ & $0,35 a$ & 0,33 a & $0,34 \mathrm{a}$ \\
\hline Diameter batang $16 \mathrm{mst}(\mathrm{cm})$ & $0,36 a$ & $0,36 a$ & $0,36 a$ & $0,35 \mathrm{a}$ \\
\hline
\end{tabular}

Keterangan: Angka pada baris dan kolom rerata diikuti huruf yang sama menunjukkan tidak beda nyata pada DMRT dengan taraf kepercayaan $95 \%$.

Tidak ada interaksi antara perlakuan jenis asam dengan komposisi media tanam pada semua variabel pengamatan. Dari Tabel 2, dapat diperoleh hasil bahwa terdapat pengaruh komposisi media tanam pada variabel pengamatan berat volume, kadar lengas, luas akar, tinggi tanaman. Penambahan pupuk kandang atau arang 
sekam memberikan berat volume yang menurun dan kadar lengas, luas akar, dan tinggi tanaman yang semakin baik. Semakin banyak pupuk kandang semakin berat volume, kadar lengas, luas akar, dan tinggi tanaman rendah. Semakin banyak arang sekam semakin berat volume rendah dan kadar lengas, luas akar, dan tinggi tanaman tinggi. Di samping itu, Tabel 2 menunjukkan bahwa tidak ada pengaruh terhadap media tanam pada variabel pengamatan lainnya.

Bobot segar dan bobot kering komposisi media tanam tanah saja tidak beda nyata dibandingkan penambahan pupuk kandang dan arang sekam namun cenderung lebih ringan. Dengan bobot segar dan bobot kering tersebut, tinggi tanaman komposisi media tanam tanah saja tidak beda nyata dibandingkan penambahan pupuk kandang dan arang sekam namun cenderung lebih pendek. Disertai dengan jumlah daun diameter batang komposisi media tanam tanah saja yang tidak beda nyata dibandingkan dengan penambahan pupuk kandang dan arang sekam. Pertumbuhan komposisi media tanam tanah saja ini terjadi karena komposisi media tanam tanah saja mempunyai kadar klorofil dan densitas stomata yang tidak beda nyata dibandingkan penambahan pupuk kandang dan arang sekam. Dilihat dari media tanam, komposisi media tanam tanah saja meskipun mempunyai berat volume lebih berat, tetapi mempunyai kadar lengas yang cenderung lebih kecil dibandingkan penambahan pupuk kandang dan kadar lengas. Dilihat dari perakarannya, komposisi media tanam tanah saja mempunyai panjang akar yang tidak beda nyata, luas akar yang cenderung lebih kecil, dan kadar air nisbi yang tidak beda nyata dibandingkan dengan penambahan pupuk kandang dan arang sekam. Disertai dengan LAB dan LPN komposisi media tanam tanah saja yang tidak beda nyata dibandingkan pupuk kandang arang sekam.

Pertumbuhan tanaman dipengaruhi oleh media tanam dan media tanam dipengaruhi oleh berat volume dan kadar lengas. Terdapat pengaruh berat volume terhadap komposisi media tanam di mana komposisi tanah saja lebih berat dibandingkan dengan komposisi media tanam lainnya. Ada pula pengaruh kadar lengas terhadap komposisi media tanam di mana komposisi arang sekam terbanyak mempunyai kadar lengas lebih banyak dibandingkan dengan komposisi media tanam lainnya pada 8 mst. Tidak ada pengaruh kadar lengas dengan komposisi media tanam di mana komposisi tanah saja sama baik dibandingkan dengan komposisi media tanam lainnya pada $16 \mathrm{mst}$.

Berat volume dan kadar lengas mempengaruhi pertumbuhan panjang akar, luas akar, dan kadar air nisbi. Telah ada pengaruh komposisi media tanam terhadap 
luas akar di mana komposisi arang sekam terbanyak mempunyai luas akar lebih luas dibandingkan dengan komposisi media tanam lainnya pada 8 mst. Tidak ada pengaruh komposisi media tanam terhadap luas akar di mana komposisi tanah saja sama dibandingkan dengan komposisi media tanam lainnya pada 16 mst. Tidak ada pengaruh komposisi media tanam terhadap panjang akar dan kadar air nisbi di mana komposisi tanah saja sama baik dibandingkan dengan komposisi media tanam lainnya pada 8 dan 16 mst.

Pertumbuhan akar mempengaruhi pertumbuhan daun. Tidak ada pengaruh komposisi media tanam terhadap luas daun, klorofil total, dan densitas stomata di mana komposisi tanah saja sama baik dibandingkan dengan komposisi media tanam lainnya pada 8 dan 16 mst. Kemampuan daun menangkap cahaya matahari, melangsungkan fotosintesis, dan menghasilkan fotosintat dilihat dari luas daun, klorofil total, dan densitas stomata mempengaruhi laju asimilasi bersih dan laju pertumbuhan tanaman. Tidak ada pengaruh komposisi media tanam terhadap laju asimilasi bersih dan laju pertumbuhan tanaman di mana komposisi tanah saja sama baik dibandingkan dengan komposisi media tanam lainnya pada 8 dan 16 mst.

Laju asimilasi bersih dan laju pertumbuhan tanaman mempengaruhi tinggi tanaman, jumlah daun, dan diameter batang. Tinggi tanaman membantu pertumbuhan daun untuk menangkap cahaya matahari dan melangsungkan proses fotosintesis. Jumlah daun menentukan kapasitas tanaman dapat melakukan proses fotosintesis. Diameter batang sebagai tempat pertumbuhan xilem dan floem untuk distribusi air, unsur hara, dan asimilat. Tidak ada pengaruh komposisi media tanam terhadap tinggi tanaman, jumlah daun, dan diameter batang di mana komposisi tanah saja sama baik dibandingkan dengan komposisi media tanam lainnya pada 8 dan 16 mst.

Pertumbuhan tanaman menghasilkan asimilat dan ada pula kandungan air di dalam tanaman yang mempengaruhi bobot segar. Tidak ada pengaruh komposisi media tanam terhadap bobot segar di mana komposisi tanah saja sama baik dibandingkan dengan komposisi media tanam lainnya pada 8 dan 16 mst. Pertumbuhan tanaman menghasilkan asimilat membentuk bobot kering. Tidak ada pengaruh komposisi media tanam terhadap bobot kering di mana komposisi tanah saja sama baik dibandingkan dengann komposisi media tanam lainnya pada 8 mst dan 16 mst.

Tanah pada penelitian ini berasal dari tanah lapisan atas kebun Pusat Inovasi Agroteknologi Universitas Gadjah Mada, di mana mengandung unsur hara yang relatif subur dan pasir yang cukup banyak (tanah regosol). Perlakuan media tanam 4:0:0 
mempunyai tekstur dan struktur dengan kandungan pasir cukup banyak dan remah. Perlakuan media tanam lainnya di mana merupakan kombinasi tanah, pupuk kandang, dan arang sekam bertujuan memperbaiki kualitas media tanam. Apabila perlakuan media tanam 4:0:0 sudah cukup subur, begitu pula dengan perlakuan media tanam lainnya. Keempat perlakuan media tanam mempunyai tekstur dan struktur tanah yang relatif sama.

Kandungan unsur hara di dalam media tanam penelitian ini relatif sama dan bibit tanaman tidak kekurangan unsur hara. Definisi sama artinya belum sampai pada batas kritis pertumbuhan bibit tanaman terpengaruh secara nyata beda nyata. Dengan demikian, media tanam yang digunakan sudah subur.

Kombinasi media tanam yang diberikan sebagai perlakuan berbeda-beda, tetapi penyiraman dilakukan dengan tidak menggenang. Walaupun, sekilas nampak penyerapan air pada perlakuan media tanam 4:0:0 lebih lambat dibandingkan perlakuan lainnya. Di samping itu, penyiraman dilakukan dengan kuantitas dan waktu yang sama di mana disiram satu mangkok setiap polibag dan setiap 2-5 hari sekali. Penyiraman mempengaruhi ketersediaan $\mathrm{O}_{2}$ dan kelembapan $\mathrm{H}_{2} \mathrm{O}$. Penyiraman yang tidak menggenang mengakibatkan ketersediaan $\mathrm{O}_{2}$ dan kelembapan $\mathrm{H}_{2} \mathrm{O}$ cukup. Penyiraman yang sama pada semua perlakuan media tanam memberikan ketersediaan $\mathrm{O}_{2}$ dan kelembapan $\mathrm{H}_{2} \mathrm{O}$ relatif sama.

Blok digunakan di penelitian ini karena adanya faktor cahaya matahari yang tidak merata. Di timur lahan terdapat bangunan dan di barat lahan terdapat pohon. Namun, hasil pengamatan menunjukkan tidak ada beda nyata antar blok sehingga cahaya matahari yang didapatkan masing-masing blok relatif sama. Delapan kombinasi perlakuan di mana dua perlakuan jenis asam dikali empat perlakuan media tanam harus ada di setiap blok. Oleh karena itu, pengacakan atau perandoman dilakukan tiga kali setiap blok di mana blok sebagai ulangan.

Adanya gejala serangan jamur pada daun dengan penampakan permukaan daun keputihan dan daun menjadi gugur. Penyemprotan fungisida Diathane M-45 2 gram per satu liter air. Penyemprotan dilakukan seminggu sekali selama empat minggu berturut-turut (pada bulan ketiga). Penyemprotan dilakukan pada bibit tanaman baik daun, ranting maupun batangnya. Adanya serangga ulat pemakan daun diatasi dengan penyemprotan insektisida Diazenon seminggu sekali. Pencegahan adanya nematoda diatasi dengan penaburan Furadan pada media tanaman sebanyak satu kali selama penelitian. Adanya gulma diatasi dengan pencabutan gulma secara manual pada dua minggu setelah tanam. 


\section{KESIMPULAN}

1. Tidak ada interaksi pengaruh komposisi media tanam terhadap pertumbuhan bibit asam manis dan asam jawa.

2. Pertumbuhan bibit asam manis lebih lambat dibanding asam jawa.

3. Tidak ada perbedaan pengaruh komposisi media tanam, meskipun penambahan pupuk kandang dan arang sekam membuat media pembibitan lebih ringan.

\section{DAFTAR PUSTAKA}

Arifin, S. Z. 2010. Pengaruh Konsentrasi Pupuk Pelengkap Cair dan Dosis Blotong terhadap Pertumbuhan Bibit Asam Manis (Sweet Tamarind). Prosiding Seminar Nasional Ketahanan Pangan dan Energi. Universitas Pembangunan Nasional Veteran Yogyakarta.

Ashari, S. 1995. Hortikultura Aspek Budidaya. Universitas Indonesia Press, Jakarta.

Azad, Md. S., N. Nahar, A. S. Mollick, dan Md. A. Matin. 2014. Variation in seedling growth of Tamarinsdus indica L.: A threatening medicinal fruit tree species in Bangladesh. Journal of Ecosystems 2014: 9.

El-Siddig, K., H.P.M. Gunasena, B.A. Prasad, D.K.N.G. Pushpakumara, K.V.R. Ramana, P. Vijayanand, dan J.T. Williams. 2006. Fruits for the Future 1 Tamarind: Tamarindus indica. Southampton Centre for Underutilised Crops, Southampton, UK.

Hamid, A. 1995. Asam Jawa Komoditas Ekspor yang Terlupakan. Trubus 305: 44-47.

Havinga, R. M., A. Hartl, J. Putscher, S. Prehsler, C. Buchmann, dan C. R. Bogl. 2010. Tamarindus indica L. (Fabaceae): Patterns of use in traditional African medicine. Elsevier Journal of Ethnopharmacology 127: 573-588.

Kuru, P. 2014. Tamarindus indica and its health related effects. Elsevier Asian Pasific Journal of Tropical Biomedicine 4: 676-681.

Rismunandar. 1986. Mengenal Tanaman Buah-Buahan. Penerbit Sinar Baru, Bandung.

Sivasankar, B. S. Rajkumar, S. Murugesh, dan A. Darchen. 2012. Tamarind (Tamarindus indica) fruit shell carbon: a calcium - rich promising adsorbent for fluoride removal from Groundwater. Journal of Hazardous Materials 225-226: 164-172.

Wongsowijoyo, S. 2013. Rempah Indonesia dan Manfaatnya. Leutikaprio, Yogyakarta. 